\title{
Una realidad lejana: la imagen de China en Terry y los piratas
}

\author{
Francisco Saez de Adana
}

Doctorado de Comunicación, Universitat Pompeu i Fabra Instituto Franklin de Estudios Norteamericanos, Universidad de Alcalá

Francisco Saez de Adana Herrero es profesor en la Universidad de Alcalá. Realiza el doctorado en el Departamento de Comunicación de la Universidad Pompeu i Fabra trabajando sobre la obra de Milton Caniff. Es miembro del Instituto Franklin de Estudios Norteamericanos de la Universidad de Alcalá donde colabora en el estudio y análisis del cómic como medio de expresión. Relacionado con este ámbito ha publicado cuatro capítulos en libros así como cinco artículos en revistas tanto nacionales como internacionales. Impartió un seminario sobre Milton Caniff y la cultura americana en la Universidad de Salerno. Organiza un curso de verano dedicado al estudio del cómic en la Universidad de Alcalá que en el año 2016 celebró su tercera edición. Es editor de Ediciones Marmotilla, editorial dedicada a la publicación de estudios teóricos sobre el medio de la historieta.

Fecha de recepción: 2 de mayo de 2016

Fecha de aceptación definitiva: 24 de mayo de 2016 


\title{
Resumen
}

En este artículo se analiza la imagen de China recibida por la sociedad norteamericana de finales de los años treinta a través de Terry y los piratas de Milton Caniff. Se muestra como la tira, al publicarse dentro de los periódicos de la época se convirtió en una de las principales fuentes de información para una sociedad fuertemente centrada en los acontecimientos locales a causa de la Gran Depresión, convirtiendo al autor en una especie de corresponsal en China. Se analiza también la imagen del oriental que la tira transmitía a los lectores de la época, considerando la raza como un elemento importante para la sociedad norteamericana.

Palabras clave: Terry y los piratas, Milton Caniff, tiras de prensa, China, orientalismo.

\begin{abstract}
China's image received by the American society of the late thirties through Terry and the Pirates by Milton Caniff is analyzed in this paper. It shows how the strip, being published in the newspapers of the time, became one of the main sources of information for a society heavily focused on local events due to the Great Depression, transforming the author in a kind of correspondent in China. Asian people image conveyed to the readers of the time by the strip is also analyzed, considering race as an important element of American society.
\end{abstract}

Keywords: Terry and the Pirates, Milton Caniff, newspaper strips, China, orientalism.

\section{Cita bibliográfica}

Saez de adana, F. «Una realidad lejana: la imagen de China en Terry y los piratas», en CuCo, Cuadernos de cómic n. ${ }^{\circ} 6$ (2016), pp. 8-33. 


\section{Introducción}

Terry y los piratas es una tira de prensa creada en 1934 por Milton Caniff, quien fue contratado por el New York Daily News para crear una nueva serie de aventuras para el Chicago Tribune New York Nerws Syndicate. La idea de la serie era del director de dicha agencia de noticias, el capitán Joseph M. Patterson, que quería una historia de aventuras situada en el misterioso oriente, que incluyera todos los elementos que la hicieran atractiva para todos los públicos: un personaje joven en busca de aventuras, un héroe atractivo que sirviera como contrapunto para las escenas de acción donde el desempeño físico fuera importante, un personaje que realizara la función de elemento cómico de la tira, la presencia de mujeres de enorme belleza y sensualidad y, finalmente, los piratas como villanos que sirvieran como desencadenantes del leitmotiv principal de la obra, la aventura. Con todos estos elementos la primera tira diaria de la serie se publica el 22 de octubre de 1934 y la primera página dominical el 9 de diciembre del mismo año, iniciando una andadura que continuaría hasta diciembre de 1946, momento en que Caniff abandona la serie, fundamentalmente porque no ostentaba la propiedad de los personajes que pertenecían al syndicate.

Como se ha comentado, la acción de la serie estaba situada en el lejano oriente y, más concretamente, en China. El objetivo de este artículo es analizar como esta obra se convierte en una de las principales fuentes de información para los estadounidenses de la época sobre los acontecimientos históricos que se estaban produciendo en los lugares donde transcurría la historia. Se estudia como la serie se va transformando de un clásico serial de aventuras a una crónica donde los acontecimientos históricos se transmiten a través de un relato de ficción. Esta labor de cronista de un lugar y de una época adquiere una mayor trascendencia considerando el impacto que la serie tenía en su momento, ya que llegó a los 35 millones de lectores. Además, su publicación en los periódicos junto a las noticias de la época producirá que, durante mucho tiempo, como se muestra en este trabajo, Terry y los piratas desempeñe una labor de nexo entre los acontecimientos históricos y el pueblo estadounidense. Se establece, por tanto, una relación entre la serie y la historia que será el elemento de análisis de este trabajo, centrado en la imagen de China con anterioridad a la Segunda Guerra Mundial.

Para el desarrollo del mismo se ha contado con la posibilidad de consultar el archivo de Milton Caniff de la Billy Ireland Cartoon Library and Museum en Columbus, Ohio, ${ }^{1}$ por

${ }^{1}$ La documentación utilizada por Caniff para su obra se conserva en el archivo de la Billy Ireland Cartoon Library and Museum en varias carpetas bajo el epígrafe «Documentación», sin catalogar y sin indicar, en la 
lo que se muestra parte de la documentación presente en ese archivo en forma de revistas de la época y correspondencia del autor, entre otros elementos que mostrarán como se establecía esta relación entre los acontecimientos históricos, el autor y el lector y como este se veía influido por la imagen de dichos acontecimientos tal y como se mostraban en la serie. Por tanto, en el artículo se realiza un análisis de la serie, considerando no solo el contenido de la misma, sino todos estos elementos adicionales derivados de su repercusión.

$\mathrm{El}$ artículo está estructurado como sigue. Tras esta introducción, se mostrará como la historia, y más concretamente en este caso la Gran Depresión, es fundamental a la hora de fijar el emplazamiento de la serie en China. A continuación, se mostrará el proceso que lleva a Caniff a transformarse en una especie de corresponsal en China sin salir de su casa en Nueva York y como la imagen que el autor transmite del país asiático deviene fundamental para entender la visión que muchos estadounidenses tenían de lo que estaba sucediendo en dicho país en cualquier momento. Posteriormente, se mostrará como Caniff es fundamental a la hora de transmitir la humanidad de los habitantes chinos superando el estereotipo oriental que existía en esa época y que algunos autores han querido ver en Terry y los piratas. Finalmente, se muestran las conclusiones de este trabajo.

\section{La Gran Depresión como catalizadora de la búsqueda de la aventura en China}

En el año 1929 las perspectivas de futuro para la sociedad norteamericana no podían ser más brillantes. E1 Ingreso Nacional Bruto había subido de 61000 millones de dólares en 1922 a 87000 millones en 1929, de tal manera que muchos negocios tenían beneficios por encima del $80 \%$ en esta década. ${ }^{2}$ Esto repercutía en el bienestar del americano medio que empezaba a disfrutar de comodidades domésticas como el frigorífico y otras de carácter más lujoso, como el automóvil, que empezó a instalarse en la mayoría de los hogares americanos en esa época. En este escenario, Herbert Hoover tomó las riendas del gobierno a principios de 1929, esperando que en muy poco tiempo la pobreza fuera a desaparecer de la nación. Nada podía hacer prever que, seis meses después, el 29 de octubre de 1929, el mercado de valores colapsaría, llevando a la sociedad norteamericana a uno de los períodos más duros de su historia, conocido como la Gran Depresión. La caída repentina de los mercados produjo una reacción en cadena, con gente perdiendo su trabajo y, posteriormente, incluso sus hogares, y aquellos suficientemente afortunados para conservar su trabajo vieron reducido su salario de forma considerable, de manera que todas las comodidades que se podían permitir anteriormente fueron desapareciendo.

La sociedad estadounidense de la época, ante este panorama económico tan desolador, encuentra una vía de escape en el entretenimiento. De acuerdo con la Encuesta de Entretenimiento Nacional de 1934, las fuentes principales de entretenimiento eran los periódicos y

mayoría de las ocasiones, fecha ni lugar de procedencia, de modo que no es posible detallar más información que la ya aportada en las citas de este artículo.

${ }^{2}$ Meltzer, M. Brother, Can you spare a dime? New York, Alfred A. Knopf, 1969, pp. 9-10. 
revistas, escuchar la radio e ir al cine, en ese orden. Aunque el precio del periódico, alrededor de tres centavos, era elevado, tres o cuatro familias lo compartían, de tal manera que una de las fuentes principales de entretenimiento pasaron a ser las tiras de cómics de los periódicos, que alcanzaron una audiencia de decenas de millones de lectores gracias a su difusión a nivel nacional como consecuencia de la aparición de los sindicatos de prensa. Muchos autores ${ }^{3}$ han comentado la necesidad de héroes y heroínas como consecuencia de esta precariedad social. Así, en la radio triunfaban shows como The Shadow o Lum y Abner, mientras que en el cine actores como Clark Gable, Gary Cooper, Fredric March junto con actrices como Carole Lombard o Joan Crawford llenaban ese vacío en el alma del ciudadano estadounidense. Las tiras de prensa no serían una excepción y 1929 vería el nacimiento del serial de aventuras en este medio con la aparición de una serie de héroes como Tarzan, Flash Gordon o Buck Rogers.

En este entorno, en 1934, nace Terry y los piratas. La historia de la creación de la tira está perfectamente documentada ${ }^{4}$ se ha comentado en la introducción. El capitán Joseph Medill Patterson, cofundador y propietario del New York Daily News y, posteriormente, en la época de la sindicación, editor del Chicago Tribune New York News Syndicate, conocedor del trabajo de Milton Caniff en series como The Gay Thirties y, sobre todo, Dickie Dare, consideró que Caniff era la persona adecuada para la creación de una nueva tira que tuviera un atractivo universal. Como se ha comentado, la Gran Depresión trajo la necesidad de héroes, pero esos héroes debían ser capaces de atraer a grandes audiencias. Patterson era consciente del papel compartido que tenía el periódico en aquella época, por lo que la nueva tira tenía que contener elementos atractivos para todos los lectores potenciales de la misma.

Un elemento fundamental de la tira es el emplazamiento. A la hora de ambientar su historia, Patterson encomienda a Caniff que la historia se ambiente en China, como último puesto fronterizo para la aventura. ${ }^{5}$ Así, con estas premisas, Caniff crea una historia en principio sencilla, de un joven americano avezado, Terry Lee, que viaja a China con su amigo periodista, Pat Ryan, a la búsqueda de una vieja mina de oro, de la que Terry ha recibido un viejo mapa de su abuelo. Varios elementos son interesantes respecto al emplazamiento en ese entorno de la Gran Depresión. El más importante es la búsqueda del oro en un territorio exótico. Esta búsqueda, que por otro lado desaparecerá muy pronto como elemento argumental de la historia, muestra la evidente necesidad de encontrar la riqueza fuera del territorio estadounidense, donde el bienestar había desaparecido y las oportunidades de encontrar esa riqueza eran escasas. Resulta curioso que el lugar de destino de los personajes sea China, mostrando como la Gran Depresión había invertido los papeles que los diferentes países jugaban en el devenir económico. No hacía tanto tiempo, entre los años 1848 y 1855, una fuerte corriente migratoria de China se había establecido en las cercanías de San Francisco como consecuencia de la conocida como «fiebre del oro». La búsqueda de oro en las

${ }^{3}$ Harvey, R. C. Meanwhile... Milton Caniff, a biography. Seattle, Fantagraphic Books, 2007; McElvaine, R. The Great Depression. America 1929-1941. New York, Times Books, 1984; Susman, W. I. La cultura como bistoria. México, EDAMEX, 1987.

${ }^{4}$ Ibid.

${ }^{5}$ Ibid., p. 194. 
costas californianas fue un fenómeno general, pero un elemento importante de la misma es la inmigración de población china tras la posibilidad de encontrar riqueza. Esta inmigración es el origen del barrio conocido ahora como Chinatown en San Francisco. El hecho de que Caniff y Patterson decidan que sus personajes tienen que desplazarse a China en busca del oro, invirtiendo la corriente migratoria que se había producido menos de un siglo antes, no es más que un reflejo del sentimiento del pueblo americano con respecto a la situación de su país. En una sociedad devastada por la pobreza y el hambre no queda lugar para la aventura. No queda ya ninguna riqueza que extraer, ya que toda se ha evaporado, y es en ese territorio desconocido donde todavía queda la esperanza de obtener riqueza, la última esperanza para la aventura.

Con esa idea no es gratuito que el capitán Patterson emplee el término en inglés outpost, aquí traducido como "puesto fronterizo», para definir a China con respecto a la aventura. En esta época de pobreza se acentúa la añoranza del americano medio con respecto a la frontera, a ese territorio que había sido la base de la creación del sueño americano y que, en cierta manera, la sociedad urbana había destruido. En una época de crisis de la sociedad urbana que, en muchos sentidos, era considerada el origen de este colapso económico, la añoranza por la frontera se intensifica. El pueblo estadounidense ha tenido como característica la emigración en la búsqueda de la conquista del territorio fronterizo. De ahí que cuando surge la necesidad, el americano medio, aún hoy en día, tiene menos reparos que otras sociedades como la europea en dejar su hogar y trasladarse en la búsqueda de mejores condiciones, generalmente, eso sí, dentro de su propio territorio. Evidentemente, una época como la Gran Depresión agudiza esa necesidad del traslado. Hay que recordar que una novela como Las uvas de la ira, quizá la más representativa de este periodo, no es más que la crónica de una emigración forzada por la situación a una búsqueda de mejores condiciones laborales y económicas. Terry y los piratas, con un carácter mucho más lúdico y aventurero, no deja de ser un reflejo de esa necesidad de la búsqueda de riqueza en nuevos territorios propia de la época.

\section{El reflejo de China o la obsesión por la realidad}

Una vez fijados los motivos para la elección del emplazamiento, en esta sección se muestra como la serie se convierte en una crónica de los acontecimientos históricos que sucedían en China durante esos años. Como se ha visto en la sección anterior el emplazamiento de la tira en tierras chinas fue, sobre todo, una imposición del capitán Patterson, al considerar China el último territorio donde podían pasar cosas, como reflejo de unos EE. UU. donde ya nada aventurero podía suceder. Sin embargo, en estos años, la población estadounidense, como reflejo de la Depresión, estaba más preocupada por los asuntos internos que por lo que sucedía en el exterior. El 5 de marzo de 1933, por ejemplo, los periódicos estadounidenses estaban centrados en el hecho de que Roosevelt había declarado ese día como el Día de Vacaciones de los bancos, cerrándolos todos pasando por alto que Hitler había ganado la mayoría en Alemania. La gente sabía muy poco de Oriente, y las «pequeñas» historias entre chinos y japoneses aparecían enterradas en los periódicos sumergidas entre todo lo relacionado con la aplicación del Nerw Deal por parte de Roosevelt. 
Caniff no era una excepción a esta regla. No había estado nunca en China y conocía muy poco sobre las sociedades orientales de la época. Lo poco que aparecía en los libros de geografía en ese momento estaba relacionado con los cultivos de arroz y los monzones. Inmediatamente después de serle encomendada la tira, se dio cuenta de que el realismo en una tira de aventuras era importante y empezó a documentarse en la biblioteca, como única fuente posible de documentación. Como el propio Caniff reconoció en una entrevista a Cosmopolitan en 1958 donde recordaba esos primeros días:

El realismo es importante. Crea una tendencia en el lector hacia la creencia de aquello que ve. La
investigación que hago no es parte de un concurso entre el público y yo; la fidelidad al detalle es
importante, es esencial para la historia exótica — no hay más que ver las obras de Joseph Conrad
y Somerset Maugham.

Sin embargo, esta obsesión por la realidad se fue desarrollando a medida que el éxito de la tira fue aumentando. Los primeros años de la serie no muestran una obsesión por el detalle tan importante como la que aparece conforme la serie fue avanzando y su éxito fue aumentando. Y la causa no es otra que la reacción del público. Como el propio Caniff afirmaba, «la reacción del público es para el artista de cómics lo que el aplauso para el actor». ${ }^{7} \mathrm{~A}$ partir del segundo año de la tira, su éxito aumentó exponencialmente y, de la misma manera, lo hicieron las cartas que, diariamente, Caniff recibía de sus lectores. Muchas de esas cartas eran para felicitarle por su trabajo o pedirle dibujos o autógrafos por parte de sus seguidores, pero también había cartas de crítica. $Y$ de esas cartas de crítica, un porcentaje muy elevado era para indicar errores que el autor había realizado en su tira. Así, cuando en la tira del 12 de febrero de 1935 muestra a un operador de radio de un barco como villano, recibe una carta de la Asociación de Radiotelegrafistas de América diciendo que «los operadores de radio se someten a un código de mayor nivel que cualquier personal marítimo» ${ }^{8}$ o comentando la tira del 17 de agosto de 1939, un lector de Cicero, Illinois, comenta que «ningún componente del ejército chino rellenaría un muñeco de serrín porque estas pequeñas partículas de madera son muy escasas y valiosas durante la guerra». ${ }^{9}$ Hasta una de las corresponsales más asiduas de Caniff, Ann Kirby, le instruía en el arte de cambiar pañales (FIG. 1).

Con todas estas reacciones, la documentación se convirtió en una obsesión para Caniff. Empezó a consumir de forma reiterada todo aquello que podía llegar en la época. Así, su imagen de China está fuertemente basada en los artículos que en aquella época se publicaban en revistas como National Geographic y Life por parte de autores como Edgar Snow, Robert F. Fitch o Hans Hildebrand, o la obra de escritores como Pearl Buck o Noel Coward. ${ }^{10}$ En este aspecto, la afirmación de Peter Burke de que «al igual que los textos y los testimonios

\footnotetext{
${ }^{6}$ Caniff, M. «Don't laugh at the comics», en Cosmopolitan, (noviembre de 1958), p. 47.

7 Ibid.

8 Bliss, W. Carta dirigida a Milton Caniff(3 de marzo de 1935). Archivo personal de Milton Caniff.

9 Matousek, B. Carta dirigida a Milton Caniff (agosto de 1939). Archivo personal de Milton Caniff.

${ }^{10}$ CAniff, M. «There had to be a choice», en The Quill. (septiembre de 1937), p. 16.
} 


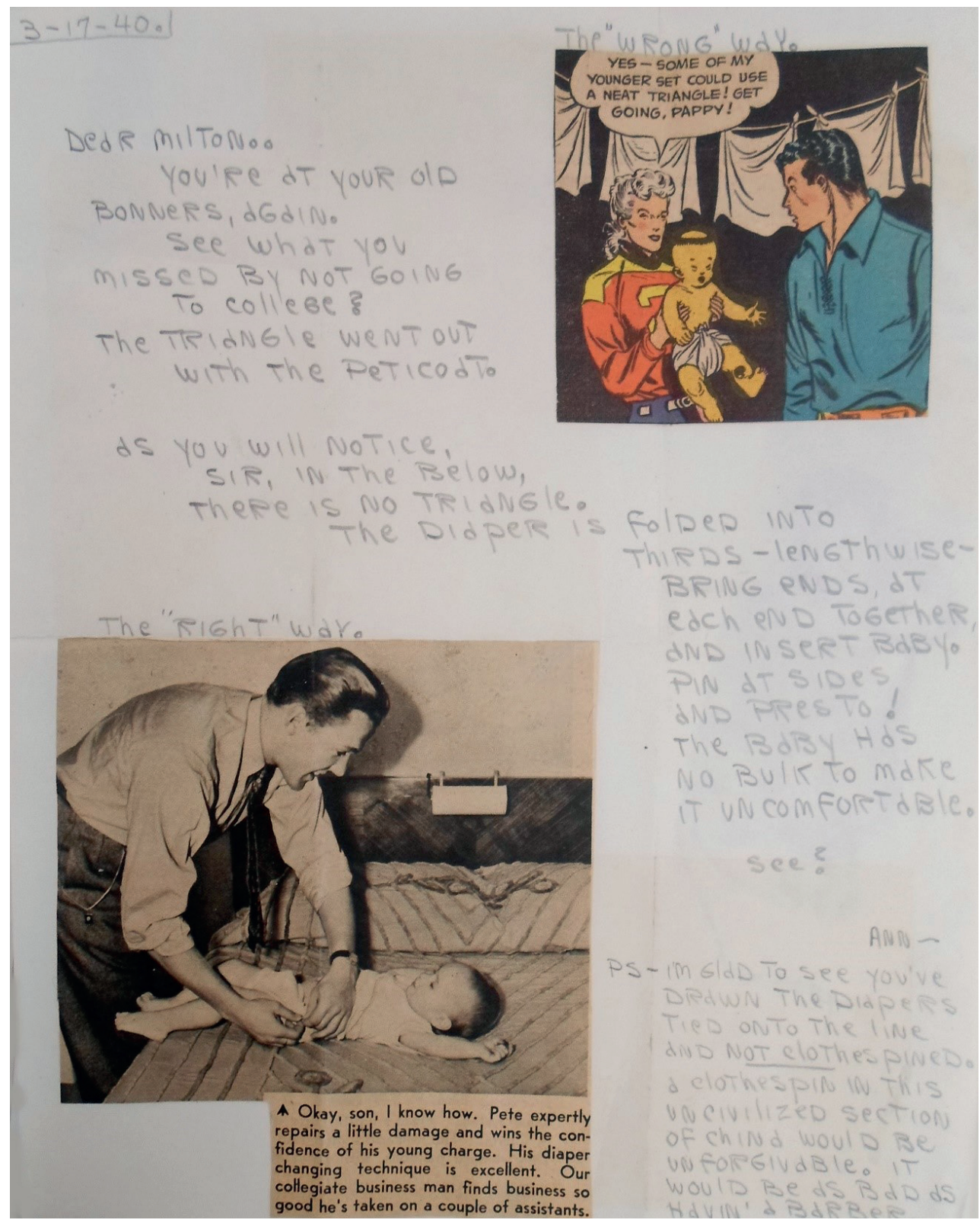

FIG. 1. Kirby, A. Carta dirigida a Milton Caniff,(17 de marzo de 1940). Archivo de Milton Caniff.

orales, las imágenes son una forma importante de documento histórico», ${ }^{11}$ se puede aplicar perfectamente a la obra de Caniff. Terry y los piratas es un perfecto testimonio histórico de la realidad en la China de la época. Un ejemplo paradigmático es el de Edgar Snow, un periodista estadounidense que entre los años 1928 y 1949 realizó, desde el propio escenario, la crónica de la revolución comunista china, incluyendo la participación de China en la

11 Burke, P. Visto y no visto. Barcelona, Crítica, 2001, p. 17. 
Segunda Guerra Mundial y el conflicto con Japón. Muchas de las imágenes de China que aparecían en la documentación utilizada por Caniff vienen de la obra del propio Snow y de los autores mencionados anteriormente. Sin embargo, el número de lectores de la obra de estos autores era mucho menor que el de Caniff en la época, de forma que se puede afirmar que la gente aprendió mucho más de China a partir de la obra del autor que de los periódicos. La mayor parte de las obras que tratan total o parcialmente su obra subrayan el hecho de que este se adelantó a muchos acontecimientos históricos antes de que estos se vieran reflejados en los periódicos o incluso de que sucedieran, como la colaboración entre la Alemania nazi y los japoneses o la invasión de Burma en la guerra chino-japonesa que en Terry y los piratas sucedió dos días antes que en la realidad y que, dados los métodos de producción de las tiras diarias, Caniff había dibujado con meses de anterioridad. Evidentemente, como el propio autor reconoce, esas anticipaciones no eran más que consecuencia de las circunstancias del momento sobre las que el autor tan profundamente se documentaba, permitiendo que el testimonio histórico se mantuviera actualizado para los lectores de la tira. Las FIG. 2 a 9 muestran varios ejemplos de esta ambientación realista utilizada por Caniff. Se puede ver que esta ambientación era importante en todos los aspectos relacionados con el entorno donde transcurría la tira, incluyendo el diseño de los barcos, las calles de las ciudades, el aspecto físico de los personajes o los paisajes abiertos, algunos de ellos tan importantes para la historia como el escenario donde sucede la muerte de Raven Sherman.

Por tanto, se puede considerar Terry y los piratas como una crónica histórica que llegaba a los lectores de forma mucho más impactante que las fuentes de información de la época. La fuerza de las imágenes y de la cultura popular, como afirman McLaughlin y Parry, «tienen el poder de influenciar nuestra manera de conocer el mundo». ${ }^{12}$ Caniff, que se consideraba a sí mismo como un Marco Polo de salón, se convirtió por el poder de sus imágenes en una verdadera autoridad en lo que concierne a la realidad de China, como demuestran muchas de las cartas que recibía. La influencia de las imágenes en la sociedad se demuestra en la reacción de esta, de la que buenos ejemplos son las respuestas de los individuos ante la potencia de esas imágenes. Así, tenemos cartas como la de un novelista que, después de vivir varios años en China, ve rechazada su novela y escribe en una carta dirigida a Caniff en diciembre de 1941:

Me estoy peleando con una novela sobre China y Little Brown me acaba de devolver 1600 palabras con tantas críticas que no sé por dónde empezar a corregir... Y lo más duro es que dice que uno de los personajes chinos no es tridimensional: los suyos viven, respiran e incluso mueren... ¿Cuántos años pasó allí? ${ }^{13}$

La imagen de China proyectada al ciudadano estadounidense medio es tan poderosa que sobrepasa la proyectada por las crónicas de la época, de tal forma que estudiantes de historia o personajes del ejército pedían información al autor sobre los sucesos que acaecían en ese país.

${ }_{12}$ McLaughlin, R. L. y Parry, S. E. We'll always have the movies. American cinema during World War II. Kentucky, The University Press of Kentucky, 2006, p. 6.

${ }^{13}$ James, H. Carta dirigida a Milton Caniff (diciembre de 1941). Archivo personal de Milton Caniff. 


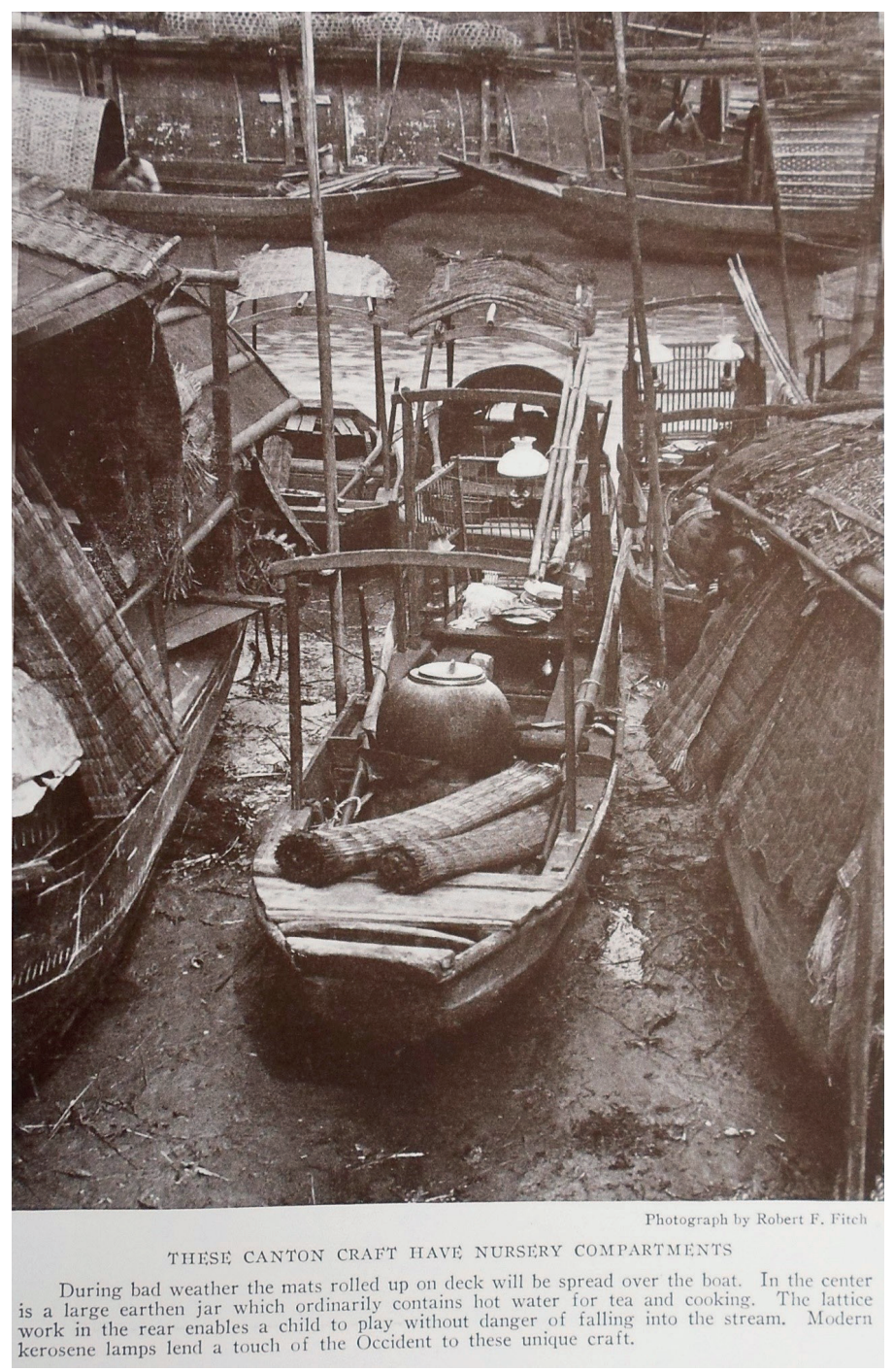

FIG. 2. Imagen del National Geographic. Archivo personal de Milton Caniff.
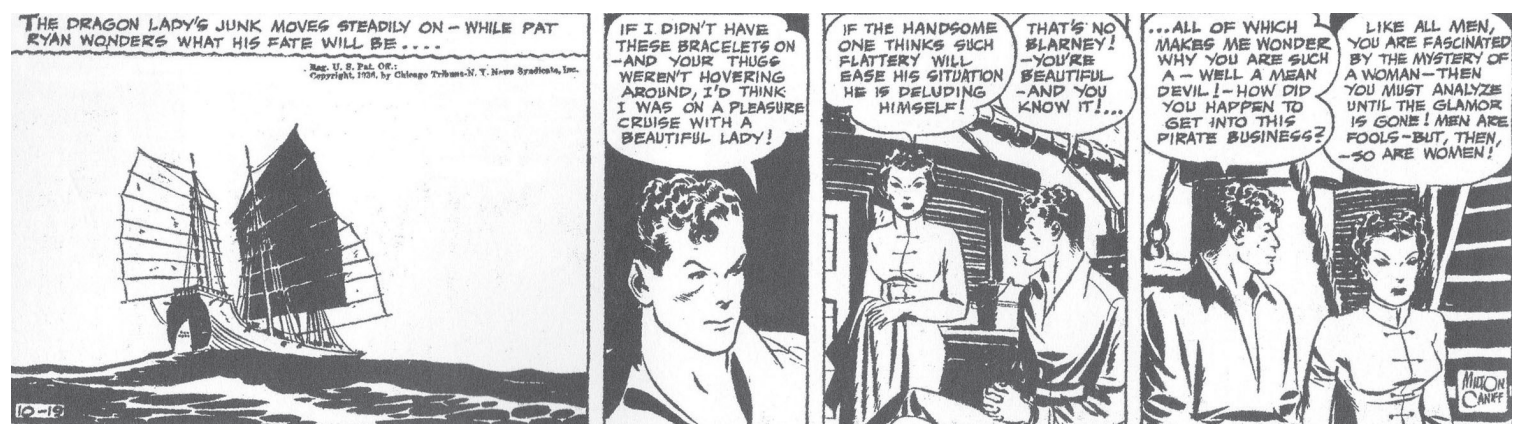

FIG. 3. Caniff, M. Terry and the Pirates, vol. 1.

San Diego, IDW Publishing, 2007, p. 332. Tira del 19 de octubre de 1936. 


\section{THE NATIONAL GEOGRAPHIC MAGAZINE}

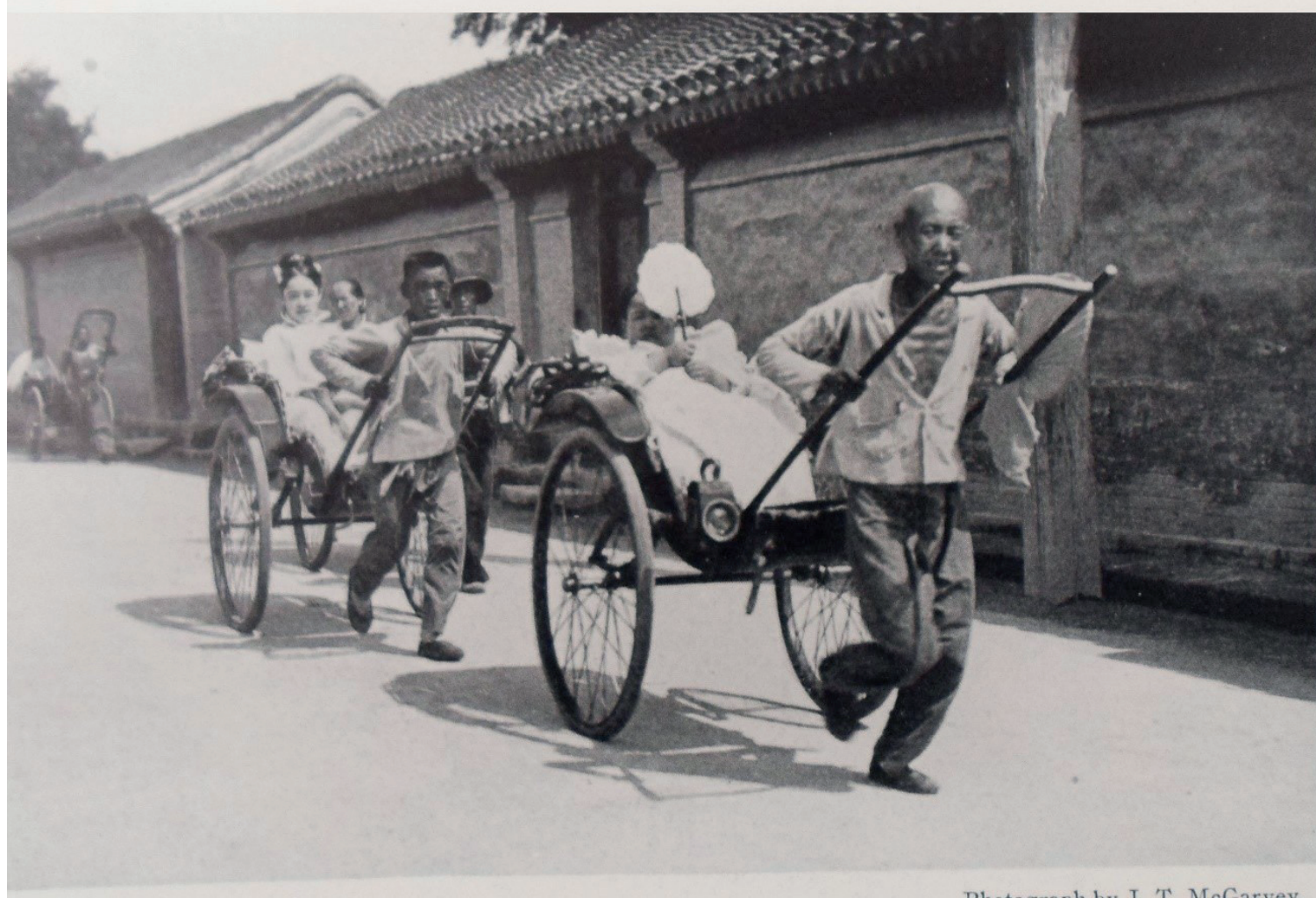

Photograph by J. T. McGarvey

FASHIONABLE RUNABOUTS IN A FORMER CHINESE CAPITAL

Well-to-do ladies of Peiping used to travel about in jinrikishas drawn by seemingly tireless coolies. These particular society vehicles are equipped with mud-guards, rubber tires, and lights.

FIG. 4. Imagen del National Geographic. Archivo personal de Milton Caniff.

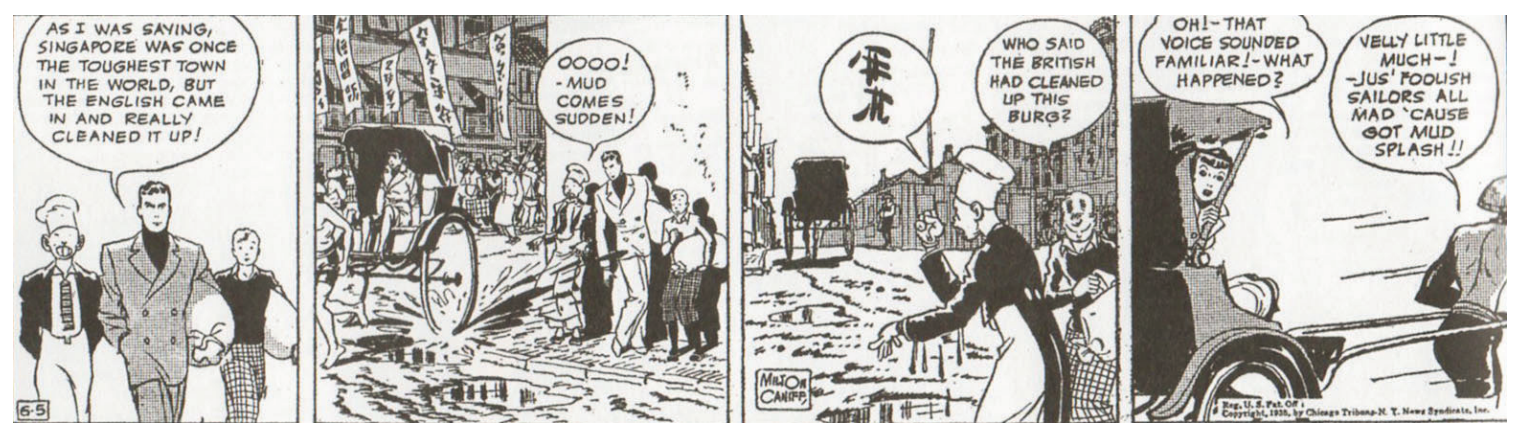

FIG. 5. Caniff, M. Terry and the Pirates, vol. 1.

San Diego, IDW Publishing, 2007, p. 180. Tira del 5 de junio de 1935 . 


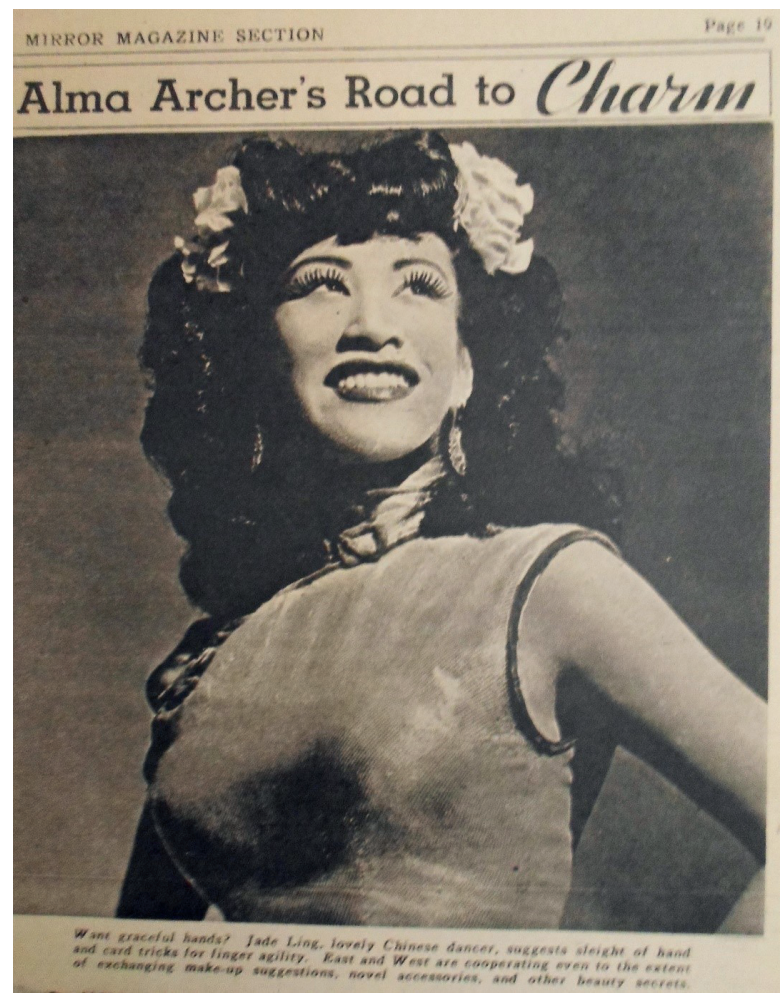

FIG. 6. Recorte de periódico. Archivo personal de Milton Caniff.

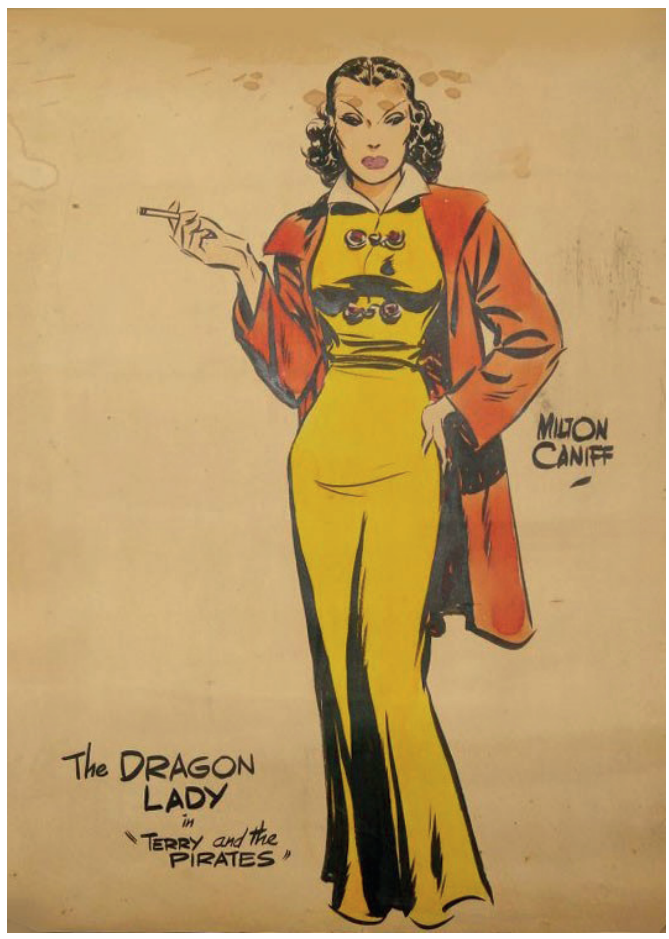

FIG. 7. Imagen de Dragon Lady. Archivo personal de Milton Caniff. 
Así, un chico de York, en Pennsylvania, escribía el 3 de noviembre de 1942 una carta diciendo: «Mis padres, que estuvieron tres años en China, siguen Terry y los piratas desde el comienzo con gran interés y admiración por su perfecta caracterización del pueblo chino y su vida». ${ }^{14} \mathrm{O}$ un miembro de la Academia Naval de EE. UU. escribía, desde Annapolis, el 10 de enero de 1941: «Su color local es especialmente interesante para mí, que solía vivir en Hong Kong. Hace un buen trabajo dibujando a los chinos y muchas de las imágenes me resultan familiares». ${ }^{15}$

Caniff, por tanto, se convirtió en un verdadero embajador de la cultura oriental en EE. UU., mostrándoles las características de una raza de la que poco conocían. La afirmación que JeanLouis Comolli hace para el cine, «son solo fotogramas, pero me muestran la vida misma», ${ }^{16}$ se podía traspasar al mundo de las viñetas, y las reacciones de los lectores ante la obra de Caniff son la mejor prueba de esta afirmación. Quizá porque dicha obra es capaz de transmitir esa realidad con una humanidad, incluso en periodo de guerra, que facilita la percepción de pueblos exóticos como eran los chinos y japoneses para la sociedad de la época como gente real. Un ejemplo de esta humanidad aparece en la página dominical del 1 de diciembre de 1940 (FIG. 10), donde los japoneses ayudan a un herido Terry. Se muestra que, al final, se trata exclusivamente de mostrar seres humanos, sin importar su procedencia, de hacerlos vivir y respirar a través de las imágenes. Se trata, haciendo un juego de palabras benjaminiano, de manifestar de forma cercana aquello que inicialmente se muestra de forma tan lejana.

\section{El estereotipo oriental}

Uno de los aspectos fundamentales a la hora de mostrar la sociedad oriental es, como bien se recoge en la carta del escritor extractada en la sección anterior, la capacidad de Caniff para que sus personajes vivan y respiren a través de sus páginas. En lo que se refiere a los personajes orientales, dos son fundamentalmente los protagonistas de la historia. Por un lado, está George Webster Confucio, también conocido como Connie, personaje que Terry y Pat alquilan como guía al principio de la historia y, por otro, Lai Choi San, conocida como Dragon Lady, una mujer voluptuosa que está basada en una pirata china y que se convertirá en una de las principales rivales de Pat y Terry desde el principio, alternando esa rivalidad con una tensión sexual primero con Pat y, cuando este empieza a crecer, con Terry, que será uno de los mayores atractivos de la serie.

Sheng-Mei Ma dedica el primer capítulo de su libro sobre el orientalismo y la identidad asiático-americana al estereotipo del oriental en los cómics de la Edad de Oro, dedicando una buena parte de ese capítulo a los personajes de Connie y Dragon Lady en Terry y los piratas. De acuerdo con Ma existen dos estereotipos de personaje oriental en la cultura po-

\footnotetext{
${ }_{14}$ Burnes, P. Carta dirigida a Milton Caniff (3 de noviembre de 1942). Archivo personal de Milton Caniff.

15 Blair. C. Carta dirigida a Milton Caniff(10 de enero de 1941). Archivo personal de Milton Caniff.

${ }^{16}$ Comolli, J. L. Filmar para ver: Escritos de teoría y crítica de cine. Buenos Aires, Cátedra La Ferla, 2002, p. 85.
} 


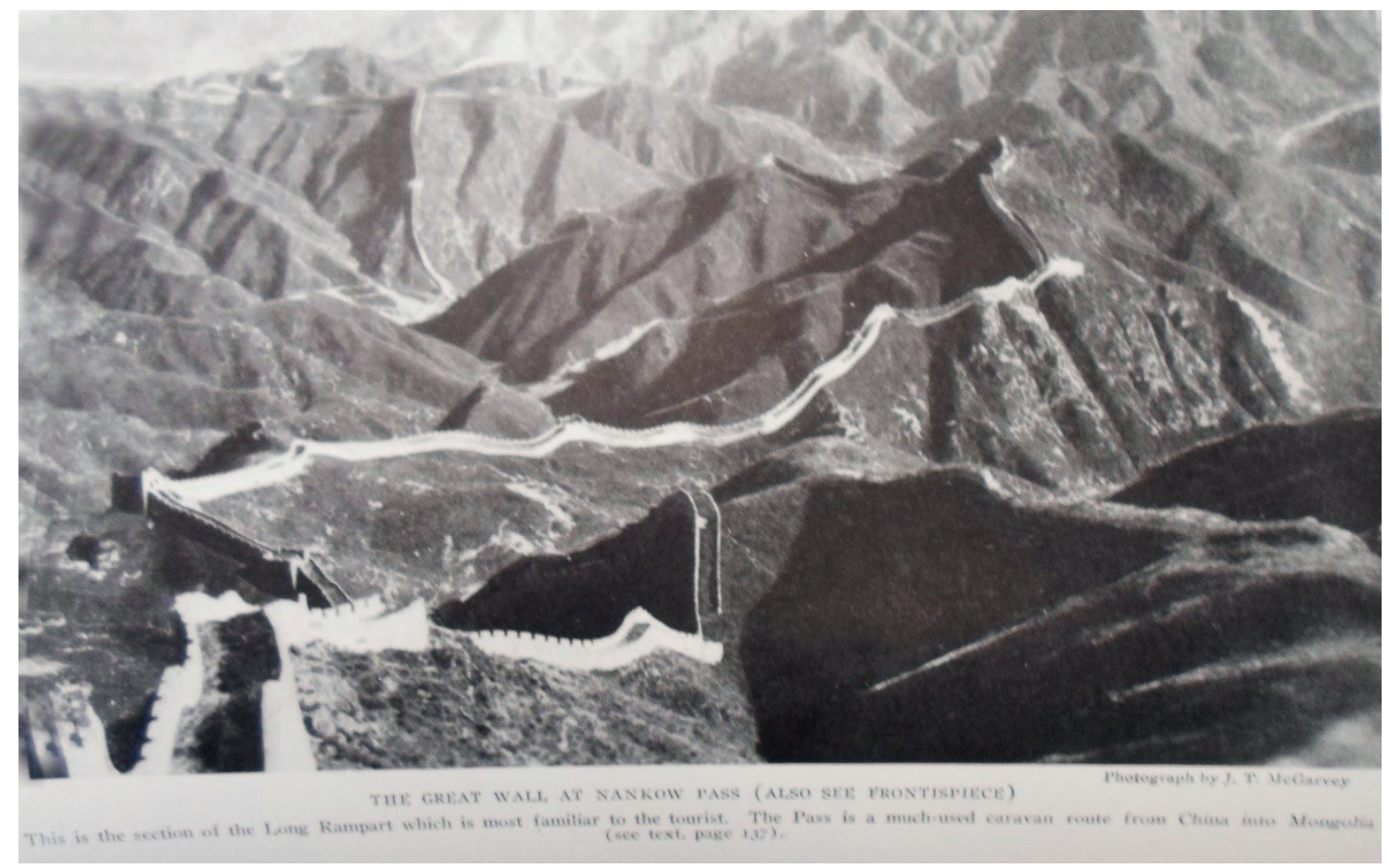

FIG. 8. Imagen del National Geographic. Archivo personal de Milton Caniff.

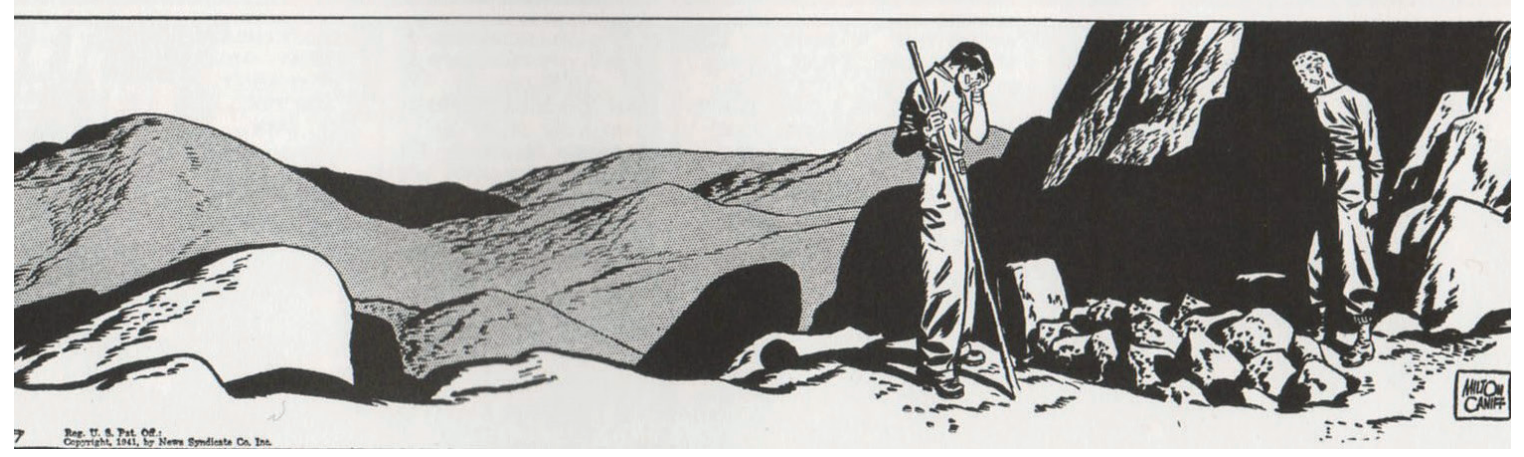

FIG. 9. Canif, M. Terry and the Pirates, vol. 4. San Diego, IDW Publishing, 2008, p. 154. Tira del 17 de octubre de 1941.

pular de esa época. Por un lado, tenemos el villano oriental, la figura siniestra proveniente del oriente que amenaza al protagonista, cuyo máximo exponente es Fu Manchú ${ }^{17}$ y, por otro lado, tenemos su reverso que es el oriental bonachón que en muchas ocasiones actúa como trasunto cómico del protagonista y cuyo máximo exponente es en este caso Charlie

${ }_{17} \mathrm{MA}, \mathrm{S} . \mathrm{M}$. The deathly embrace. Orientalism and Asian American identity. Minneapolis, University of Minnesota Press, 2000, p. 9. 
Chan. ${ }^{18} \mathrm{Ma}$ analiza en su capítulo como el personaje de Connie cae en el estereotipo de elemento cómico heredero de Charlie Chan y Dragon Lady en el estereotipo de villano heredero de Fu Manchú. No se puede negar que muchos de los argumentos son ciertos, pero si se considera que una tira como Terry y los piratas constituye un reflejo de la realidad, entre otras cosas por la capacidad de sus personajes para mostrar vida, el hecho de caer en el estereotipo no facilitaría esa labor. Es bien cierto que, sobre todo en los primeros años de la tira, donde la obsesión por la realidad era menos manifiesta, los rasgos estereotípicos eran mayores: estos años son, por otro lado, los que mayoritariamente recoge Ma en su estudio. Sin embargo, a medida que la tira evoluciona y Caniff va siendo más cuidadoso en la creación de un imaginario que respire verosimilitud, los personajes se alejan de este estereotipo. Si ya se ha comentado anteriormente que uno de los elementos que contribuyen de forma más acusada a esa sensación de realidad es la capacidad de Caniff de infundirles humanidad, incluso en aquellos personajes más secundarios e identificados con el enemigo, esta característica se hace más acusada en los personajes principales.

En esta sección se analizan aquellos aspectos de los personajes que contradicen la idea de Ma de que sean estereotipos orientales, mostrando que aunque los aspectos que esta autora señala están ahí, existen otros que muestran un carácter tridimensional de los personajes
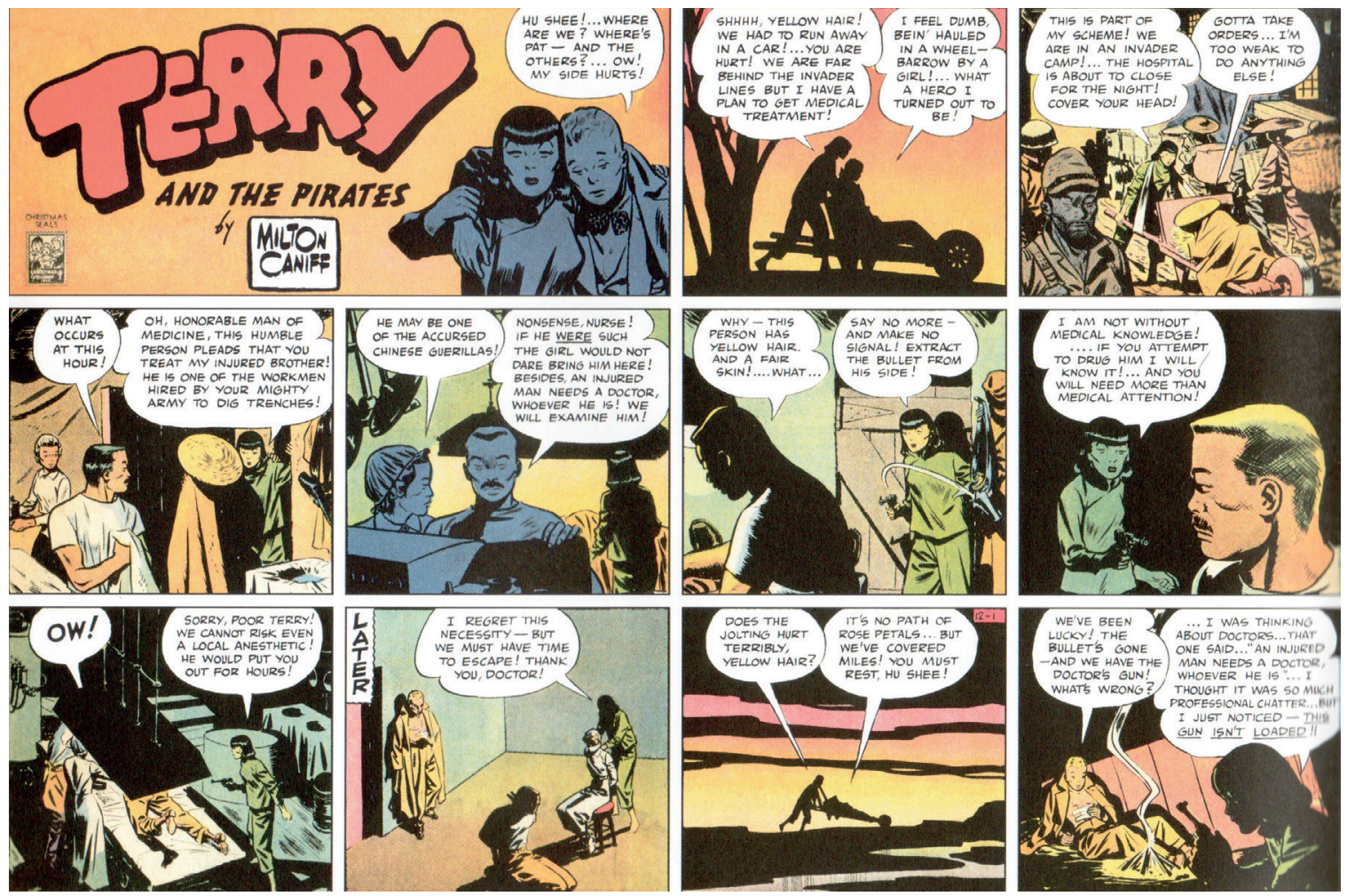

FIG. 10. CAniff, M. Terry and the Pirates, vol. 3. San Diego, IDW Publishing, 2008, p. 332. Página dominical del 1 de diciembre de 1940.

18 Ibid., p. 13. 
y que se pasan por alto en el análisis mencionado. Es interesante dedicar un espacio a este tema, ya que evidentemente si estamos tratando el reflejo de la historia en una obra donde aparecen personajes de tan diferentes culturas, no se puede evitar un aspecto tan controvertido de la sociedad norteamericana de esta época y de todas las épocas como son las diferencias entre razas. La idea de esta sección no es, por tanto, contradecir el trabajo de Ma, sino mostrar un aspecto de la historia norteamericana como es la preocupación en el tratamiento de las diversas razas. Preocupación que tiene unos fundamentos históricos innegables en una sociedad construida sobre los cimientos de la esclavitud, pero que a veces hace que se magnifiquen elementos en las obras artísticas de forma ciertamente parcial.

Comenzando por Connie, es evidente que este personaje nace como contrapunto cómico de los protagonistas y ya se ha puesto de manifiesto anteriormente. Su aspecto (FIG. 11) junto con su comportamiento son propios del estereotipo de Charlie Chan comentado anteriormente. Incluso algunas de sus expresiones son meramente cómicas. El hecho también de que empiece como sirviente de los protagonistas agudiza este carácter de inferioridad del personaje oriental. No estoy tan de acuerdo, sin embargo, en otro de los elementos que destaca Ma, que es el acento que introduce Caniff en el personaje de Connie. Caniff hace hablar a Connie de una manera que trata de reproducir, por medio de la tipografía, la forma

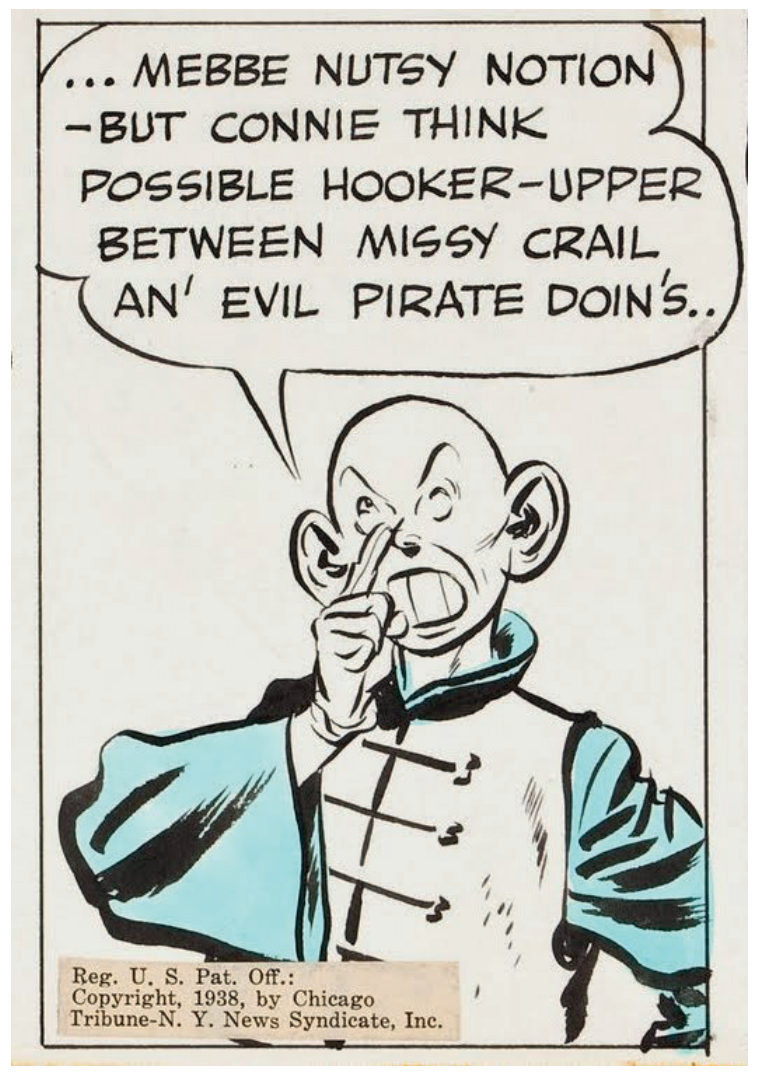

FIG. 11. Caniff, M. Terry and the Pirates, vol. 1. San Diego, IDW Publishing, 2007, p. 18. Imagen de Connie. 


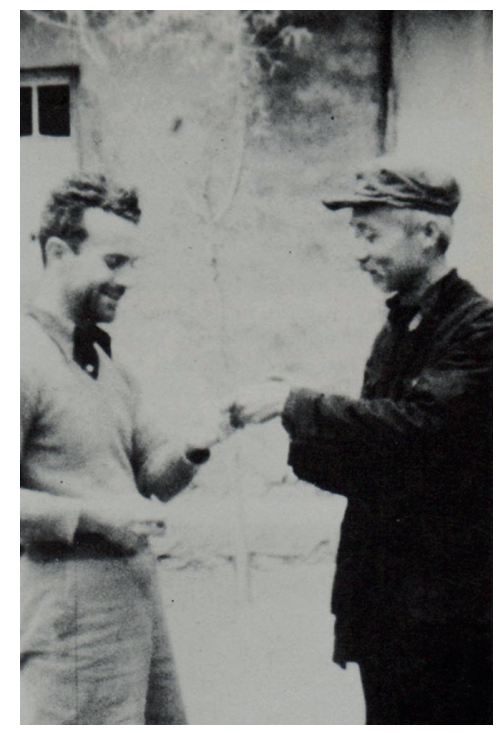

FIG. 12. Fotografía de Edgar Snow. Archivo personal de Milton Caniff.
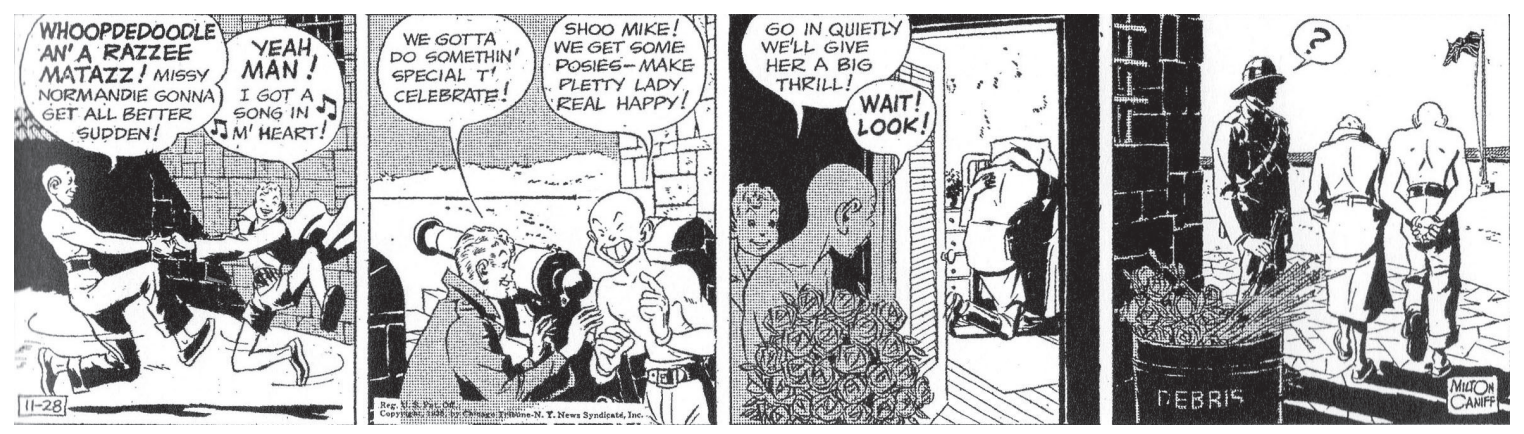

FIG. 13. Caniff, M. Terry and the Pirates, vol. 1. San Diego, IDW Publishing, 2007, p. 231. Tira del 28 de noviembre de 1935.
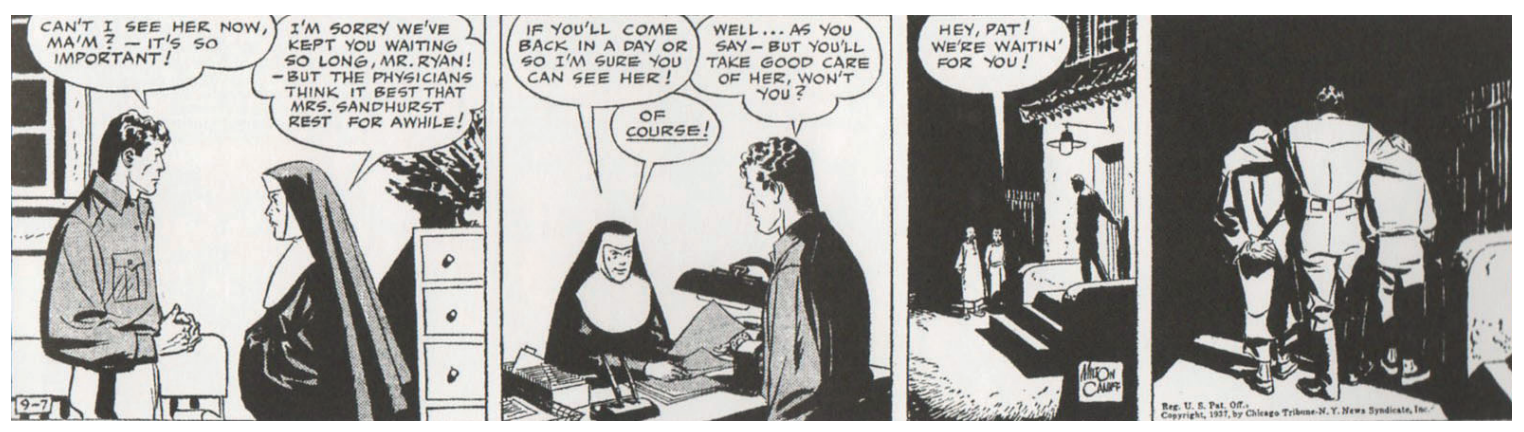

FIG. 14. Caniff, M. Terry and the Pirates, vol. 2. San Diego, IDW Publishing, 2007, p. 139. Tira del 7 de septiembre de 1937. 
de hablar de los habitantes chinos. Sin embargo, esto, que evidentemente en ocasiones se utiliza de modo cómico, no deja de ser una manera más de Caniff de reflejar la realidad. Todos los personajes de Caniff de origen ajeno al británico o estadounidense muestran esa característica. El capitán Blaze, mencionado antes, de origen escocés, refleja en su manera de hablar el fuerte acento de esa parte de Gran Bretaña. Cuando aparecen personajes alemanes tienen un supuesto acento alemán. Se trata de reflejar, en la medida en la que un medio como el cómic lo permite, el crisol de culturas que se daban cita en la China de la época. $\mathrm{Si}$ se entiende esto como un signo de racismo, debería entenderse hacia todas las culturas y no exclusivamente hacia la oriental.

Milton Caniff ha sido acusado repetidamente de ser un autor conservador, entre otros por otros dibujantes de cómics preocupados por el reflejo de la historia como Carlos Giménez, que rechazó la entrega de un premio al autor en el certamen de cómics de Gijón por considerarlo «el autor de historietas más reaccionario de toda la historia del cómic mundial». ${ }^{19}$ Bajo mi punto de vista, su trayectoria en los primeros años está lejos de ser conservadora, sufriendo una evolución a lo largo de los años paralela a la de buena parte de la sociedad estadounidense y, especialmente, las instituciones militares. Esta idea desde el punto de vista de la raza queda de manifiesto en estos primeros años de la tira. Caniff recibe el encargo de dibujar una tira en China con un personaje cómico y, desde su ignorancia de americano medio, dibuja ese personaje con rasgos orientales y con una clara inferioridad con respecto a los protagonistas principales de origen anglosajón. Sin embargo, según su tira va derivando del escapismo propio de la tira de aventuras a convertirse en un reflejo de la historia, fruto del conocimiento adquirido por el autor gracias a su esfuerzo documental, sus personajes evolucionan y huyen de ese estereotipo que, como bien recoge Ma, era propio de la sociedad estadounidense de la época. Como se ha comentado, Caniff bebe de la imagen de China que proyectan periodistas como Edgar Snow y, en las obras de estos periodistas no hay lugar para el estereotipo ni muestras de un sentimiento de superioridad. La FIG. 12 muestra una foto de Snow en una actitud de camaradería con el ejército chino. Imágenes de este estilo pueblan sus crónicas. Siguiendo esta idea, el personaje de Connie evoluciona muy pronto de ese elemento cómico inferior a un verdadero compañero de aventuras de los protagonistas, salvándoles en muchas ocasiones la vida, con actuaciones que demuestran sobradamente una inteligencia paritaria con sus camaradas. Pero sobre todo, existen suficientes elementos a lo largo de la tira para demostrar que los personajes de Pat y Terry consideran a Connie su igual. Cuando Pat se plantea cobrar un cheque por su labor heroica, tanto Terry como Connie son conscientes de que lo va a repartir con ellos, alegrándose por igual. Pero se puede ver también en las tiras del 28 de noviembre de 1935 (FIG. 13) como, por un lado, Terry y Connie se alejan como compañeros cuando descubren que Pat está besando a Normandie o como, ante la imposibilidad de ver a la propia Normandie, Pat se retira apesadumbrado abrazando a ambos por igual en la tira del 7 de septiembre de 1937 (FIG. 14). Hay una relación de complicidad y camaradería que abarca a los personajes sin importar su raza. Existe una evolución con la historia del tratamiento del personaje oriental, fruto de la preocupación de Caniff de recoger fielmente el comportamiento de las diferentes culturas.

$\overline{19}$ «El dibujante Carlos Giménez rechaza un premio», en El País (24 de julio de 1979), p. 40. 
Esta preocupación por el tratamiento de la raza se recoge en la carta del 15 de octubre de 1945 donde una mujer de Welton le pregunta sobre la posible inclusión en la historia de un personaje de raza negra y su posterior respuesta del propio autor, donde manifiesta:

Si el negro o negros se convierten en el clásico comediante de los musicales de bajo nivel, las protestas justificadas de los negros aparecerán inmediatamente. Si se le muestra como un individuo perfectamente normal, vendrán las protestas y cancelaciones de los periódicos del sur. Si se incluyen ambos tipos, significa dedicar toda una secuencia a las actividades de los negros, lo que, con seguridad, traerá protestas de los periódicos del sur. ${ }^{20}$

Esta preocupación, que puede parecer de otro tiempo, demuestra ser una preocupación inherente a la sociedad estadounidense, como se verá más adelante, especialmente en lo que se refiere a la comunidad afroamericana, pero también, como demuestra el estudio de $\mathrm{Ma}$, a la comunidad asiático-americana. Creo que existen elementos que justifican la tesis de Ma como reflejo de la sociedad de la época, pero también una evolución del tratamiento por parte de Caniff, fruto de su preocupación por el reflejo de la realidad de otras culturas.

El caso de Dragon Lady es aún más fascinante. De nuevo hay una evolución de un estereotipo a un personaje totalmente tridimensional. Puede haber algunos elementos de amenaza oriental en las primeras historias de la serie, pero rápidamente estos quedan diluidos por el carácter de femme fatale del personaje. Si a algún imaginario se puede decir que responde el personaje de Dragon Lady es al de las femme fatale del cine negro, según Nuria Bou «figuración moderna de la imaginación seductora y nefasta de Pandora». ${ }^{21}$ Uno de los argumentos que emplea Ma, para demostrar la inferioridad de Dragon Lady como personaje oriental es el hecho de que, pese a su fortaleza como jefa de una banda de piratas, cae inmediatamente subyugada ante los encantos de Pat Ryan. En primer lugar, esta afirmación sería discutible. $\mathrm{El}$ atractivo entre los dos personajes es evidente, pero en ningún momento Dragon Lady deja que su relación con Pat Ryan interfiera en sus objetivos, sean estos moralmente dudosos o, como sucederá posteriormente, absolutamente encomiables. Por otro lado, esa tensión sexual entre Pat y Dragon Lady no es más que una expresión en la tira diaria de la confrontación entre el régimen diurno y el régimen nocturno que, siguiendo a Gilbert Durand, también interpreta Bou en el cine clásico y que aparece en una obra como la de Caniff, con tantas interacciones con el cine de su época. No existe ningún componente racial, bajo mi punto de vista, en la relación entre Pat y Dragon Lady. En todo caso se podría acusar de occidentalizar el personaje. Por un lado, Dragon Lady está inspirada en Joan Crawford, pero, por otro, el comportamiento de Pat hacia Dragon Lady no difiere del que tiene hacia la otra femme fatale fundamental del primer periodo de la tira, Burma, personaje eminentemente de raza aria, pero cuya relación de dominador(a)-dominado(a) con respecto al personaje masculino protagonista es muy similar, como muestran estas imágenes del 20 de marzo de

${ }^{20}$ Caniff, C. Carta dirigida a Murlee Hart (10 de julio de 1945). Archivo de Milton Caniff.

${ }^{21}$ Bou, N. Diosas y tumbas. Mitos femeninos en el cine de Hollywood. Barcelona, Icaria, 2006, p. 20. 

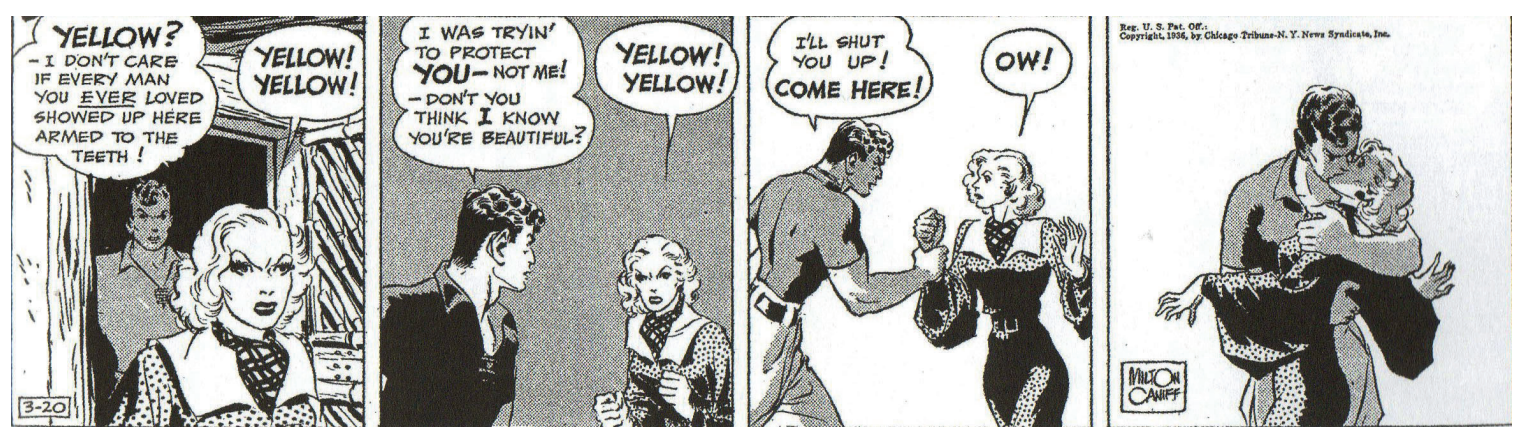

FIG. 15. Caniff, M. Terry and the Pirates, vol. 1. San Diego, IDW Publishing, 2007, p. 263. Tira del 20 de marzo de 1936.
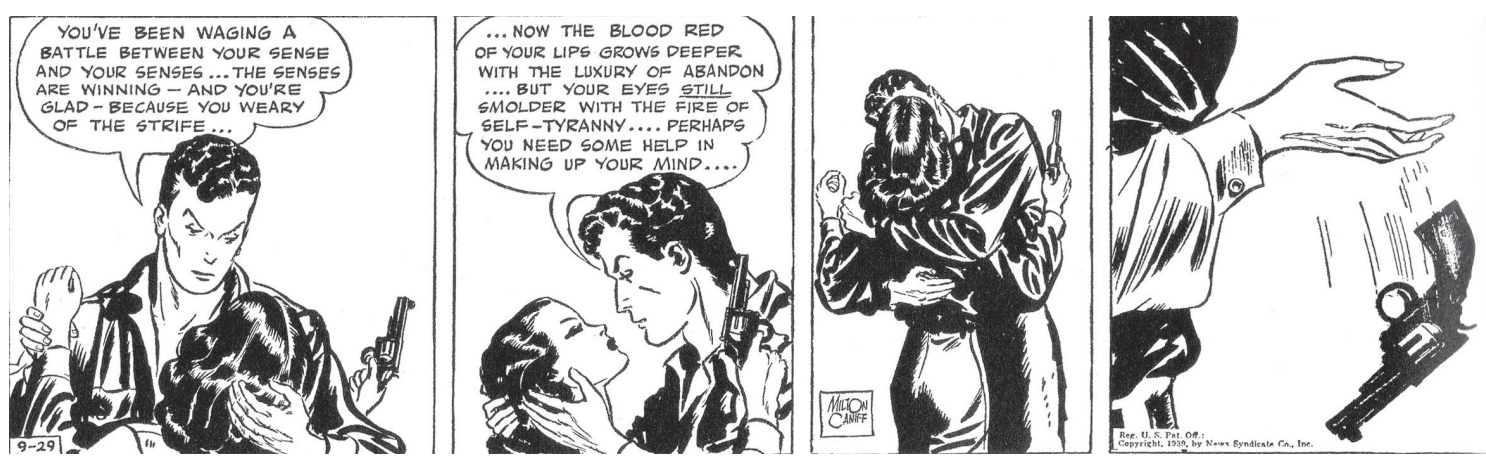

FIG. 16. Caniff, M. Terry and the Pirates, vol. 3.

San Diego, IDW Publishing, 2008, p. 148. Tira del 29 de septiembre de 1939.

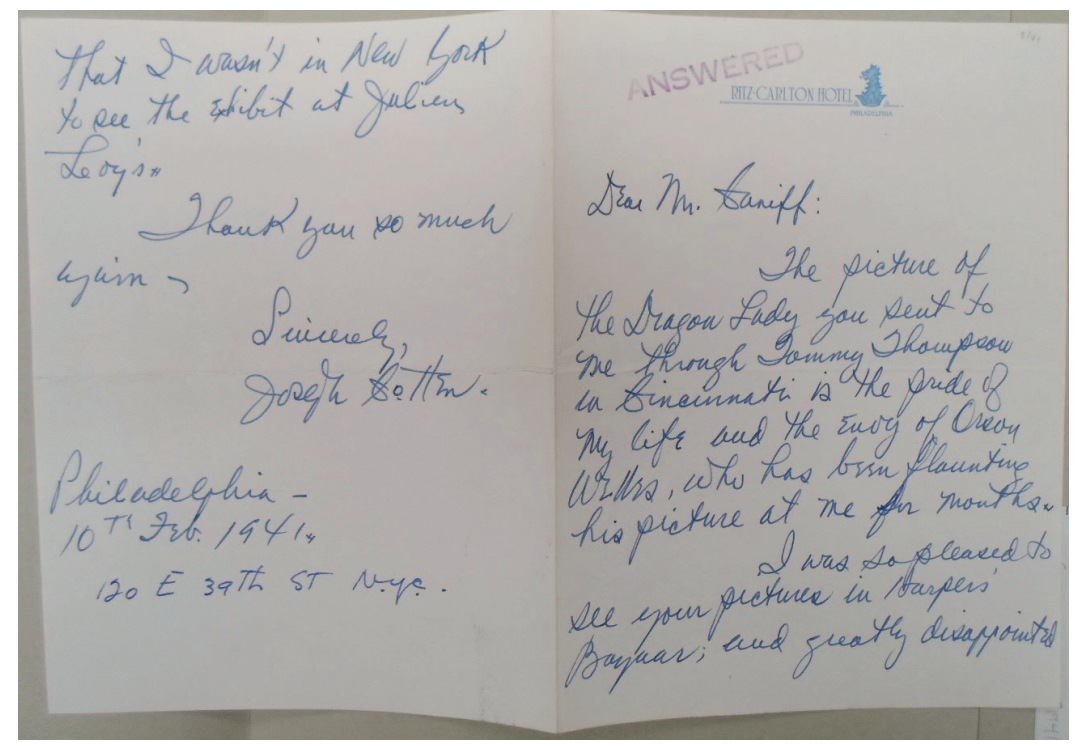

FIG. 17. Сотten, J. Carta dirigida a Milton Caniff (10 de febrero de 1941). Archivo personal de Milton Caniff. 
ORSON WELLES

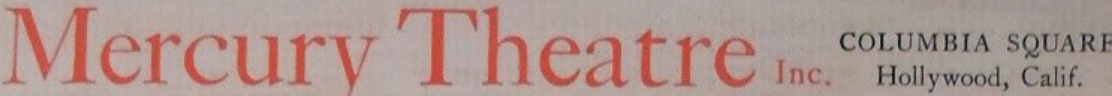 \\ Hollywood 6365}

Mercury Text Records

Mercury Shakespeare (Harper \& Bros.)

Mercury Theatre on The Air

The Campbell Playhouse

Orson Welles-Mercury Productions (RKO Radio Pictures)

November 10th, 1939.
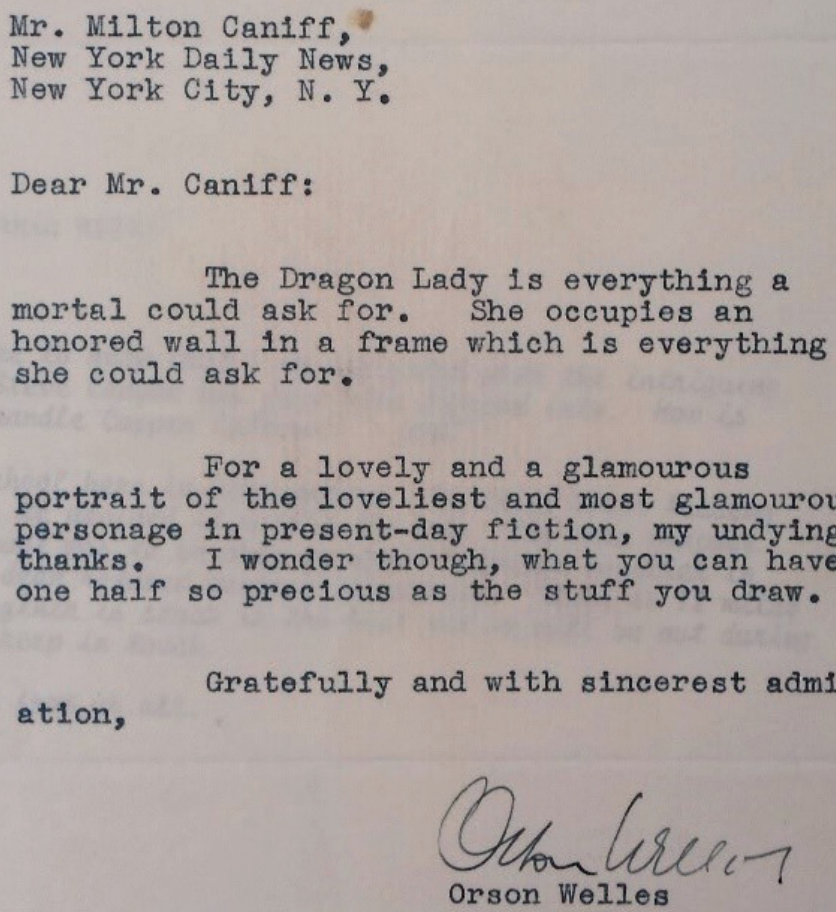

OW :W

FIG. 18. Welles, O. Carta dirigida a Milton

Caniff(10 de noviembre de 1939). Archivo per-

sonal de Milton Caniff. 
1936 (FIG. 15) y del 29 de septiembre de 1939 (FIG. 16). Los personajes de Burma y de Dragon Lady son vistos como dos muestras de la femme fatale sin atender a la diferencia de raza. La correspondencia recibida por Caniff contenía en un gran número peticiones de lectores que querían dibujos de Dragon Lady o de Burma, a veces en situaciones de elevado erotismo. Se puede encontrar una evidencia casi por igual para ambos personajes. No parece, por tanto, que exista un componente diferencial en el tratamiento de las razas. Se trata, por tanto, de un estereotipo femenino que levanta oleadas de deseo como muestra alguna de estas cartas de remitentes tan famosos como Orson Welles o Joseph Cotten (FIG. 17 y 18). Ejemplos como estos proliferan en la correspondencia de Caniff.

Por otro lado, poco se puede decir en cuanto a estereotipos de un autor que introduce una de las escenas de amor interracial más bellas de la historia de cualquier medio, la de Terry con Hu Shee, del 23 de enero de 1941 (FIG. 19), personaje por otro lado diametralmente opuesto a Dragon Lady, demostrando la posibilidad de construir personajes de todo tipo, fueran de la raza que fueran.

En referencia, de nuevo, al personaje de Dragon Lady y, más concretamente, a su representación como estereotipo de villano oriental tal y como lo define Ma, poco más se puede decir
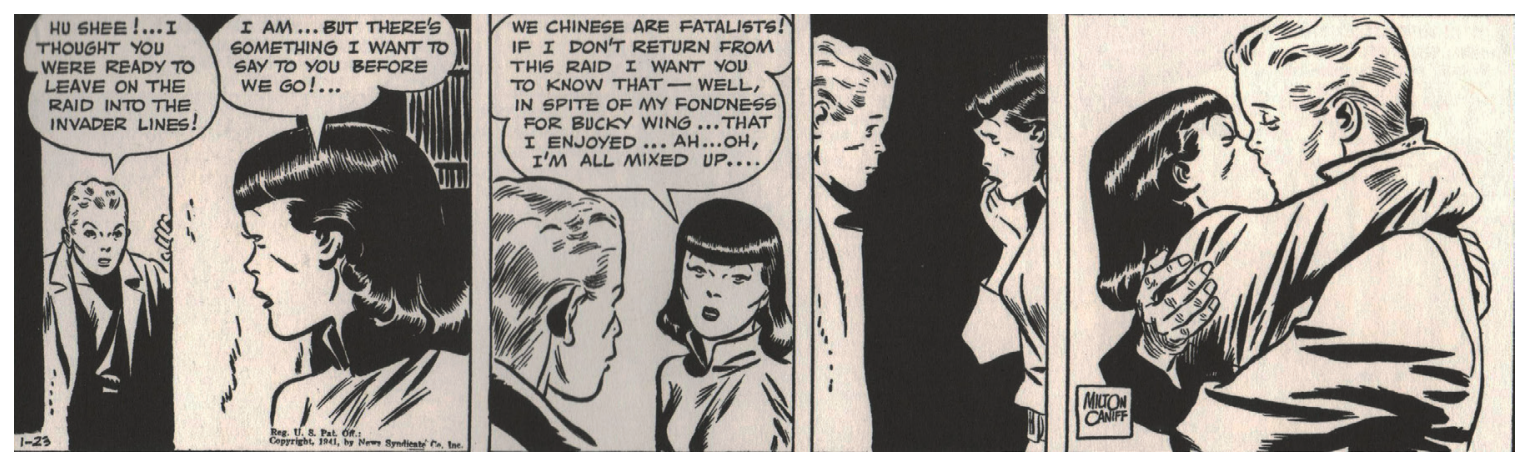

FIG. 19. Caniff, M. Terry and the Pirates, vol. 4.

San Diego, IDW Publishing, 2008, p. 40. Tira del 23 de enero de 1941.
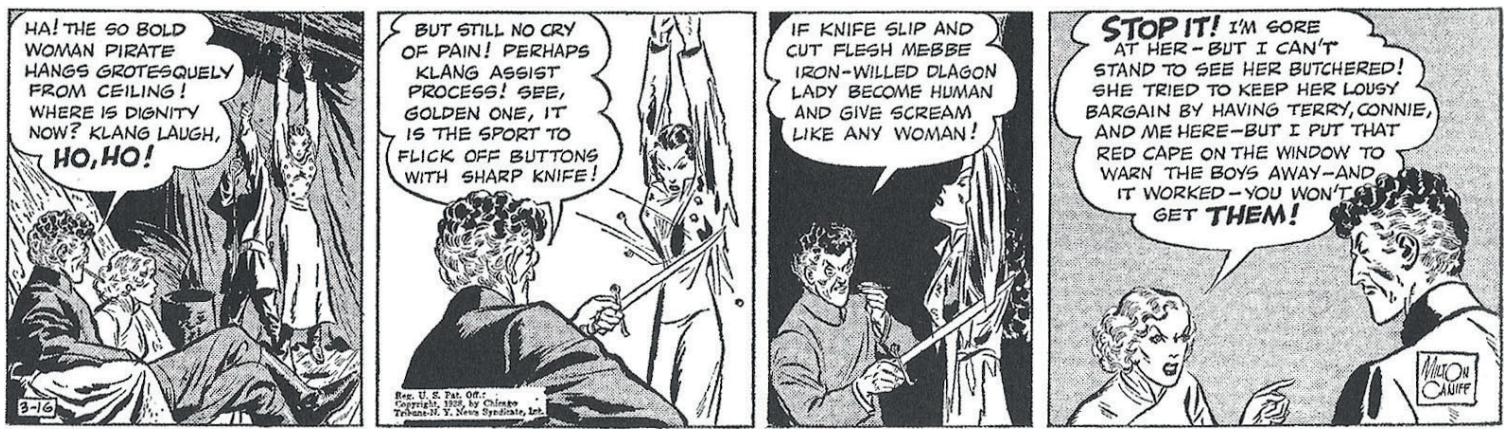

FIG. 20. Caniff, M. Terry and the Pirates, vol. 2.

San Diego, IDW Publishing, 2007, p. 220. Tira

del 16 de marzo de 1938. 
teniendo en cuenta que es un personaje que evoluciona de pirata sin escrúpulos a jefa de la resistencia china cuando se produce la invasión japonesa. Aunque se excuse en la necesidad de luchar contra los japoneses para preservar su riqueza, es evidente el carácter patriótico del personaje de Dragon Lady en esa época. No se trata, por tanto, de desmontar las tesis de $\mathrm{Ma}$, sino de poner de manifiesto un elemento fundamental a la hora de mostrar el reflejo de la historia en una obra y este es su posterior interpretación. Las cuestiones de discriminación racial son una parte fundamental de la historia estadounidense. Caniff, como ciudadano americano de la época, cae en muchas de ellas como se ha comentado, pero también introduce muchos elementos que demuestran una apertura de miras que es importante reconocer. La humanidad de sus personajes es, finalmente, lo que hace su historia tan valiosa como documento histórico, y en esa humanidad está incluida la propia del autor que a veces le hace caer en el estereotipo, pero que un análisis más detenido de la obra demuestra que existiendo ese factor, no es más que una faceta de la capacidad poliédrica de sus personajes. Sin embargo, el análisis de Ma, es, por otro lado, también un reflejo histórico. Un reflejo, como se ha comentado anteriormente, de la preocupación de la sociedad norteamericana por los conflictos raciales y la discriminación positiva, que una historia de opresión ha hecho necesaria, que todavía tiene vigencia hoy día. La imagen mostrada en la FIG. 20 de Dragon Lady atada para ser torturada por el villano Klang es cuestionada en varias cartas de los lectores, por ejemplo el editor asociado del Tulsa Tribune, uno de los periódicos que publicaban la tira que dice «simplemente habiendo enseñado como la llevaban a ser atada y luego saliendo de la escena no hubiera dañado tu historia». ${ }^{22}$ Cuando en el número 28 de The Walking Dead el gobernador (un villano que, por otro lado, recuerda al Klang de Terry y los piratas, como se puede ver), viola y golpea salvajemente al personaje de Michonne (FIG. 21), esta carta se publica en el número 32 de la serie.

Como hombre de descendencia africana, me sentí molesto debido a la imagen de una mujer negra fuerte y poderosa, despojada de su poder y de su humanidad siendo violada y apaleada brutalmente por un hombre blanco no una, sino dos veces, en el mismo número. (...)

Entiendo la idea del efecto dramático en la narrativa, pero maldita sea, ¿debía atarse a Michonne desde arriba para ser violada y torturada? ¿Tiene una mujer negra que ser destrozada hasta lo más profundo? ¿Es un caso del arte imitando a la vida en el sentido de que si los negros son demasiado fuertes no solo se los debe detener, sino también destruir? ¿No podrías haber sometido algún personaje blanco al mismo tratamiento? No creo que lo hicieras. Nunca se ve a personajes blancos femeninos en los cómics siendo deshumanizados de esta manera. Te garantizo que el destino de Michonne no lo compartirán Supergirl, Power Girl ni, ciertamente, Wonder Woman. (...)

Te evitaré una diatriba interminable sobre cómo la violación de mujeres africanas fue parte del proceso de deshumanización durante la esclavitud, pero te diré que conozco muchos lectores afroamericanos de The Walking Dead que también han expresado su disgusto sobre el retrato de una mujer negra violada por un hombre blanco. Algunos me han dicho que no van a leer nunca más la serie. Las lectoras negras que conozco también han expresado su disgusto. (...)

No sé si puedo seguir leyendo (la serie) después de esto. ${ }^{23}$

${ }^{22}$ Lloyd, J. Carta dirigida a Milton Caniff(28 de marzo de 1936). Archivo personal de Milton Caniff.

23 Aвubakari, S. Carta aparecida en la sección de cartas del lector de The Walking Dead, n. 32 (octubre de 2006). 

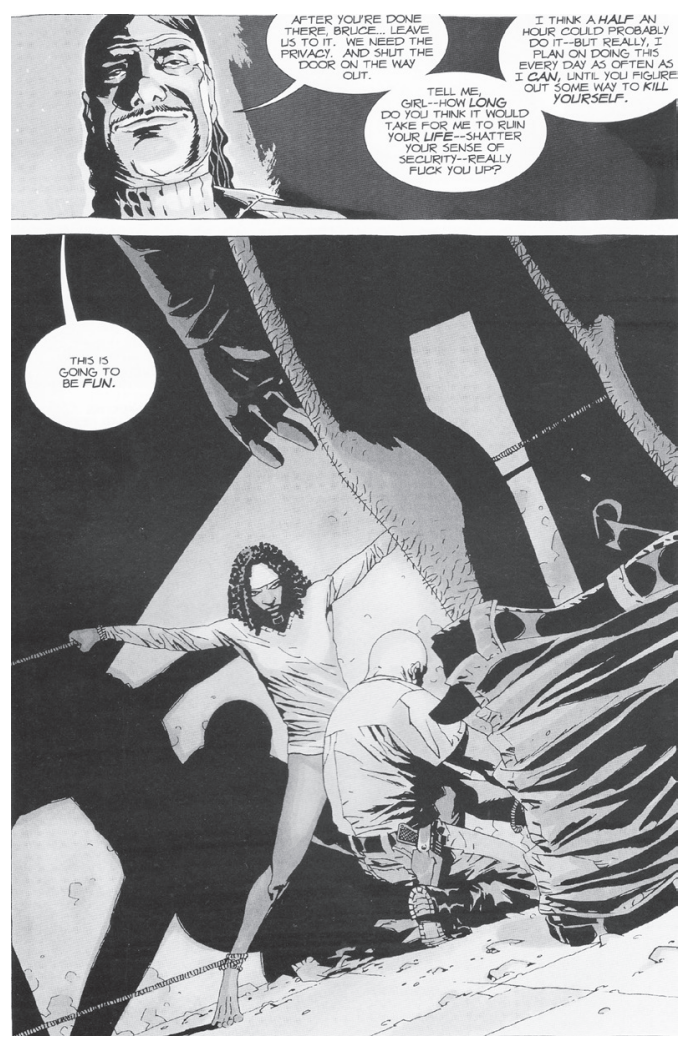

FIG. 21. Kirkman, R., Adlard, C. The Walking Dead, n. 28 (junio de 2006), p. 22.

Robert Kirkman se defiende en la propia sección de cartas argumentando que toda clase de tragedias suceden en esta serie a personajes tanto blancos como negros. Como se ve el conflicto racial es un elemento inherente de la historia de EE. UU. que encuentra su reflejo en las viñetas y, sobre todo, en la reacción de la sociedad ante lo que en ellas se muestra.

\section{Conclusiones}

En este trabajo se ha analizado el papel de las tiras de prensa, en general, y de una obra como Terry y los piratas en particular, como imagen de la historia y, especialmente, de la visión que la sociedad norteamericana tenía de la China de finales de los años treinta, justo con anterioridad al comienzo de la Segunda Guerra Mundial. Esta era la época dorada del cómic de prensa como medio de comunicación que llegaba a millones de lectores, ligado siempre al periódico, lo que convertía la actividad de la lectura de este tipo de cómic en algo cotidiano y, además, fuertemente ligado a la actualidad. De esta forma, se ha visto como una serie como Terry y los piratas juega un papel fundamental como crónica de la historia. $\mathrm{El}$ aspecto particular de la serie es que está ambientada en un territorio desconocido para el ciudadano estadounidense que no ocupaba mucho espacio en una prensa ocupada fundamentalmente por la economía doméstica. Se ha mostrado como el autor poco a poco va transformando la serie en una historia exótica de aventuras a una crónica de la realidad, 
impulsado por una obsesión por el realismo creada por la reacción de los propios lectores, lo que manifiesta una bidireccionalidad en la relación entre la obra como imagen de la historia y la sociedad estadounidenses. Muchos son los aspectos que se podrían analizar en este papel de crónica y de reflejo social, pero en este trabajo se han cubierto aquellos que se han considerado más relevantes, como la necesidad de la búsqueda de la riqueza en territorios exóticos consecuencia de la Gran Depresión, o la transmisión del papel de los estadounidenses en territorio chino que tan poco reflejo tenía en las noticias de la época. Finalmente, en una obra centrada en la relación entre diferentes culturas, un elemento como el de la diferencia entre razas tan intrínseco a la sociedad de EE. UU. no puede dejarse de lado. Por este motivo se ha mostrado como el tratamiento de la raza es una preocupación a la hora de afrontar una labor de este tipo y como tiene un impacto en el lector, impacto que, como se ha visto, continúa hasta nuestros días en obras más recientes. Esta preocupación por una discriminación racial hace, en muchas ocasiones, destacar elementos de una obra como discriminatorios. Sin embargo, estos elementos, en el global de la obra, no pueden entenderse de la misma manera. Pero esta preocupación por la discriminación, demuestra que es un aspecto importante de la sociedad norteamericana que encuentra su reflejo en su reacción ante las obras de ficción como se ha mostrado en este trabajo.

\section{Agradecimientos}

Este trabajo ha sido posible, en parte, gracias a la Beca Benjamin Franklin otorgada por el Instituto Franklin de la Universidad de Alcalá.

El autor quiere agradecer a Iván Pintor Iranzo por su estimable ayuda en la realización de este trabajo. 


\section{Bibliografía}

Bou, N. Diosas y tumbas. Mitos femeninos en el cine de Hollywood. Barcelona, Icaria, 2006.

Burke, P. Visto y no visto. Barcelona, Crítica, 2001.

CAniff, M. «Don't laugh at the comics», en Cosmopolitan (1958, noviembre), pp. 43-47.

— «There had to be a choice», en The Quill (1937, septiembre), pp. 6-17.

- Terry and the Pirates, vol. 1-6. San Diego, IDW Publishing, 2007-2009.

Comolli, J. L. Filmar para ver: Escritos de teoría y crítica de cine. Buenos Aires, Cátedra La Ferla, 2002.

Harvey, R. C. Meanwhile... Milton Caniff, a biography. Seattle, Fantagraphic Books, 2007.

MA, S. M. The deathly embrace. Orientalism and Asian American identity. Minneapolis, University of Minnesota Press, 2000.

McElvaine, R. The Great Depression. America 1929-1941. New York, Times Books, 1984.

McLaughlin, R. L., Parry, S. E. We'll always have the movies. American cinema during World War II. Kentucky, The University Press of Kentucky, 2006.

Meltzer, M. Brother, Can you spare a dime? New York, Alfred A. Knopf, 1969.

Mumford, L. The culture of cities. Nueva York, Harcourt, Brace \& Co, 1938.

Susman, W. I. La cultura como historia. México, EDAMEX, 1987.

«El dibujante Carlos Giménez rechaza un premio», en El País (24 de julio de 1979), p. 40.

The New York Times. Edición del 7 de mayo de 1929, p. 15. 